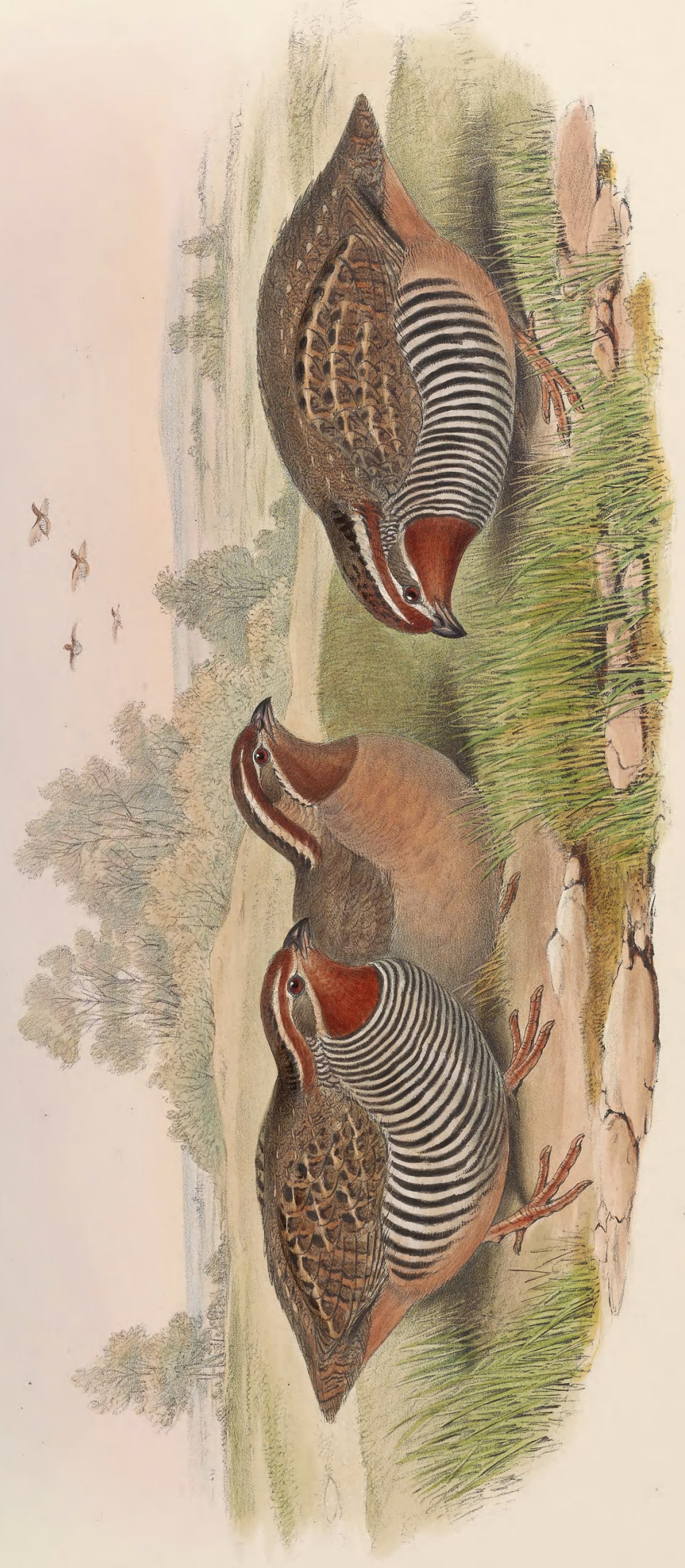

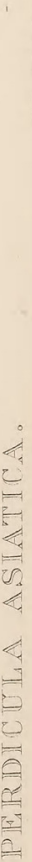




\section{PERDICULA ASIATICA.}

\section{Asiatic Bush-Quail.}

Perdix asiaticus, Lath. Ind. Orn., vol. ii. p. 649.

Asiatic Partridge, Lath. Gen. Syn. Supp., vol. ii. p. 278.-Lath. Gen. Hist., vol. viii. p. 281

Coturnix rubiginosa, Gray and Mitch. Gen. of Birds, vol. iii. p. 507.

Coturnix Pentah, Sykes, in Proc. of Comm. of Sci. and Corr. of Zool. Soc, part ii. p. 153.--Id. Trans. Zool. Soc., vol. ii. p. 19, pl. 3.-Jerd. Madras Journ. of Lit. and Sci., vol. xii. p. 6.

Perdicula asiatica, Blyth, Cat. of Birds in Mus. Asiat. Soc. Calcutta, p. 254.-Adams in Proc. Zool. Soc., part xxvi p. 504.-Blyth, Ann. \& Mag. Nat. Hist., vol. xx. p. 322.

Lowa, Hind, Blyth

Thene are no birds more puzzling to the ornithologist than the two species of little Bush-Quails inhabiting India, for which Mr. Blyth has proposed the generic name of Perdicula - the variation in their colouring and markings being almost infinite, and running one into the other in such a manner that it is impossible to separate a collection of specimens into their proper species with any degree of certainty; every ornithologist, however, admits that there are two distinct species inhabiting the peninsula of India-one, the $P$. asiatica, being very generally dispersed over the greater part of the country, while the other, $P$. argoondah, occurs in the Madras Presidency and some of the south-western provinces. The males of both species are said to have their breasts strongly crescented-with black on a white ground, while the adult female is of a uniform buffy brown; or if the uniformity be broken, it is only by an increase of colour in the gorget. The young during the first year, and probably for a longer period, have their backs mottled and freckled with markings of brown and buff in an infinite variety of forms.

"These birds," says Col. Sykes, speaking of the Bush-Quails of the Dukhun, "are met with only on the mountains, on the slopes and sides of which they rise in coveys from amidst reeds and long grass and brushwood, with the same startling whirl, uttering cries of alarm, as C. argoondah. My specimens were shot at 4000 feet above the sea."

Dr. Adams, on the other hand, states that it "frequents the valleys of the lower ranges of the Western Himalayas, is gregarious and migratory. Its food consists of small seeds, such as mustard. Rises with a quick whirring noise; flies only a short distance, frequently dropping into the nearest bush, where it secretes itself. I have not seen this species on the plains of India."

Mr. Jerdon says, "It is an inhabitant of all the forests of S. India, and also occasionally and more sparingly found in low jungles and wooded nullahs in the Carnatic and other regions. It is found at all levels, from the neighbourhood of the sea to the summits of the lofty mountains of the Western Ghauts."

The following is, I believe, a correct description of the two sexes.

The male has the forehead, a broad stripe over the eye, and the throat-gorget rich reddish chestnut; above the red stripe over the eye a narrower streak of buffy white; through the eye, from the base of the bill, a narrow line of white, and a third narrower line below the eye of the same colour; ear-coverts brown; all the upper surface marbled with light brown, dark brown, and buff, some of the dark markings being in small, others in large blotches, while the paler ones assume the form of streaks, spots, and bars; tail alternately barred with irregular lines of black and rich buff; breast, abdomen, and flanks numerously and alternately barred with black and greyish white; vent, thighs, and under tail-coverts pale rufous; irides dark red; bill slaty black, with a flesh-coloured base; legs red.

The female has the head and throat marked very like that of the male; all the upper surface light brown, minutely freckled with darker brown; the scapularies and tertiaries streaked with buff, and marked with large and conspicuous blotches of brownish black near the tip of the inner web; under surface vinous red; irides, bill, and legs as in the male.

The Plate represents two males and a female, of the size of life. 


\section{$2 \mathrm{BHL}$ Biodiversity Heritage Library}

Gould, John. 1863. "Asiatic Bush-Quail, Perdicula asiatica [PI. 4]." The Birds of Asia 7(XV), -. https://doi.org/10.5962/p.323426.

View This Item Online: https://www.biodiversitylibrary.org/item/122491

DOI: https://doi.org/10.5962/p.323426

Permalink: https://www.biodiversitylibrary.org/partpdf/323426

\section{Holding Institution}

Smithsonian Libraries

\section{Sponsored by}

Smithsonian Institution Libraries

\section{Copyright \& Reuse}

Copyright Status: Not in copyright

This document was created from content at the Biodiversity Heritage Library, the world's largest open access digital library for biodiversity literature and archives. Visit BHL at https://www.biodiversitylibrary.org. 